http://jmscr.igmpublication.org/home/

ISSN (e)-2347-176x ISSN (p) 2455-0450

crossref DOI: https://dx.doi.org/10.18535/jmscr/v7i9.05

Journal Of Medical Science And Clinical Research

\title{
Clinicopathological Study of Chronic Lower Limb Ulcers and Management
}

\author{
Authors \\ Dr Akkidas. Suvarchala. M.S ${ }^{1}$, Dr Tabbassam Aura M.S ${ }^{2}$, Dr Shaik Sohail ${ }^{3}$ \\ ${ }^{1}$ Associate Professor [Designated], Department of General Surgery, King George Hospital, Andhra Medical \\ College, Visakhapatnam, Andhra Pradesh \\ ${ }^{2}$ Civil Assistant Surgeon \\ ${ }^{3}$ Postgraduate in Department of Surgery, Andhra Medical College, Visakhapatnam, Andhra Pradesh \\ *Corresponding Author \\ Dr A. Suvarchala M.S \\ D. No: 6-1-1/1, M.V.V Estates, Chinawaltair, Visakhapatnam -530017, India
}

\begin{abstract}
Introduction: Ulceration of the lower extremity is a common condition that causes significant discomfort and disability. An ulcer is defined as a disruption of the skin with erosion of the underlying subcutaneous tissue. This breach may extend further to the contiguous muscle and bone. The pathophysiological mechanisms underlying ulcer formation are multi-factorial and include neuropathy, infection, ischemia, and abnormal foot structure and biomechanics.

Aims and Objectives: To compare and analyse the distribution of age, sex, systemic disease in lower limb ulcers among 100 cases of the study group. To study the clinical features of various types of leg ulcers. To study the usefulness of applied investigations. To carefully manage the condition.

Patients and Methods: The present study "CLINICOPATHOLOGICAL STUDY OF CHRONIC LOWER LIMB ULCERS AND MANAGEMENT”' was done at Department of General Surgery in Andhra Medical College, King George Hospital during the period between July 2015 to October 2017.

Source of Data: During this period all the lower limb ulcers which were admitted to various surgical units and attended surgical OPD at King George Hospital were included in this study.

Type of study: Prospective study with detail history taking \& clinical examination

Statistical Analysis: Statistical analysis was done by using MS Excel 2007.

Observations and Results: The most common cause of lower limb ulcer was found to be Diabetes mellitus (29\%) followed by traumatic ulcer (18\%).Youngest patient was 13years and oldest 70years. Case volume was found to be maximum in the age group >50years (46\%) signifying that ulcers occur frequently in older age group. Males were found to be predominantly affected (70\%).Diabetic ulcers were found to be highest in the age group $>50$ years (58.62\%). There was marked male preponderance (86.2\%).Venous ulcers were found to be greatest in the age group $>50$ years (64.2\%). Males were found to be maximally affected (57.14\%).Long saphenous system is the most common venous system affected in venous ulcers (85.72\%). Trendelenberg procedure combined with GSV Stripping \& split thickness skin graft was the procedure employed in treatment of al 12 cases. Peripheral vascular disease in the affected limb was diagnosed by absent peripheral arterial pulsations and Color Doppler. Atherosclerosis was found to be the most common cause of arterial ulcers (57.14\%). Among Trophic ulcers, 60\% were in diabetics, $20 \%$ in hemiplegics and 20\% in Hansen's disease. Most common malignant ulcer in my study was Marjolins ulcer (60\%) all of which had history of burns in the past. Remaining were Squamous cell carcinoma (40\%). The most common exudate in the present study is serous (54.16\%) followed by purulent(43.76\%) and greenish exudates (2.08\%). Lower limb ulcers were found to be more common in left limb (60.49\%). Out of total 100 patients of chronic lower limb ulcers,
\end{abstract}


$41 \%$ underwent debridement, 25\% underwent split skin graft, 14\% underwent Trendelenburg operation with Great/ short saphenous vein ligation with perforator ligation, 10\% underwent amputation,7\% underwent lumbar sympathetectomy and rest 3\% underwent plastic surgery consultation for reconstruction.

Conclusion: Multi-disciplinary team approach and establishing specialized wound care centres appear to confer a significant, positive impact on reducing recurrent ulcerations and amputations. A detailed knowledge of the clinical picture, pathogenesis, diagnostic tests, treatment modalities, and differential diagnosis of leg ulcerations is essential in planning the optimal treatment strategy.

Keywords: chronic ulcer, diabetic ulcer, venous ulcer, debridement, grafting.

\section{Introduction}

Ulceration of the lower extremity is a common condition that causes significant discomfort and disability. An ulcer is defined as a disruption of the skin with erosion of the underlying subcutaneous tissue. This breach may extend further to the contiguous muscle and bone. The pathophysiological mechanisms underlying ulcer formation are multi-factorial and include neuropathy, infection, ischemia, and abnormal foot structure and biomechanics.

A chronic ulcer is defined as a full-thickness skin defect with no significant re-epithelialization for more than 4 weeks. Three etiologies of leg ulcerations are responsible for almost $95 \%$ of leg ulcers: about $40 \%$ to $80 \%$ are due to underlying venous disease, $10 \%$ to $20 \%$ are due to arterial insufficiency, and $15 \%$ to $25 \%$ are secondary to diabetes mellitus; in $10 \%$ to $15 \%$ of patients, a combination of two or more causes exists.

The disease entities that usually underlie leg ulceration (e.g., venous insufficiency, peripheral artery disease (PAD), diabetes mellitus) are associated with significant patient morbidity and mortality. A detailed knowledge of the clinical picture, pathogenesis, relevant diagnostic tests, treatment modalities, and differential diagnosis of leg ulcerations is essential in planning the optimal treatment strategy. An incorrect or delayed initial diagnosis may harm the patient and increase the risk of serious complications, including permanent disability and amputations.

The cost of treating leg ulcers is staggering. Because the disease affects a patient's lifestyle and attitude, the social cost of leg ulcers accrue. The ability to work may be temporarily or permanently affected by the condition. Hence treatment of these patients proves to be a challenging task.
Wound therapy has advanced considerably over the past few decades with the advent of innovative dressings and technologies, but the key factor in the management of chronic ulcers remains proper patient evaluation and correction of the underlying cause, once identified. Hence an attempt is made in the present study to address and assess various ulcers of lower limb.

\section{Aims and Objectives}

- To compare and analyse the distribution of age, sex, systemic disease in lower limb ulcers among 100 cases of the study group.

- To study the clinical features of various types of leg ulcers.

- To study the usefulness of applied investigations.

- To carefully manage the condition.

\section{Patients and Methods}

The present study "CLINICOPATHOLOGICAL STUDY OF CHRONIC LOWER LIMB ULCERS AND MANAGEMENT" was done at Department of General Surgery in Andhra Medical College, King George Hospital during the period between July 2015 to October 2017.

Source of data: During this period all the lower limb ulcers which were admitted to various surgical units and attended surgical OPD at King George Hospital were included in this study.

Type of study: Prospective study with detail history taking \& clinical examination

- Investigations:

$>$ Blood and urine investigations include $\mathrm{Hb} \%$, TC, DC, ESR, Serum Creatinine, Lipid profile, FBS/PPBS, screening tests for Hepatitis B,C 
antigens \& HIV, Urine for albumin, sugar, microscopy.

$>$ Specific investigations: X-ray of the affected foot, Pus for culture \& sensitivity from ulcer, Biopsy from the ulcer edge, Colour Doppler for arterial ulcers \& diabetec ulcers, Duplex scanning for venous ulcers.

- Appropriate management of the ulcer by

$>$ Debridement under anaesthesia followed by regular dressing of the ulcer done till its infective nature is curtailed and healthy granulation is seen.

Evaluation of the preoperative status of $\mathrm{Hb} \%$, correction of anemia, hypoproteinemia, hypertension, glycemic control so that patient can be made fit for surgery.

Surgical treatment according to the specifics of the case.

$>$ Post-operative management regarding control of diabetes, hypertension, nutritional support, regular wound care.

Rehabilitation through adjunctive foot wear was advised in selected indicated cases

Figure 3: Age Distribution of Lower Limb Ulcers

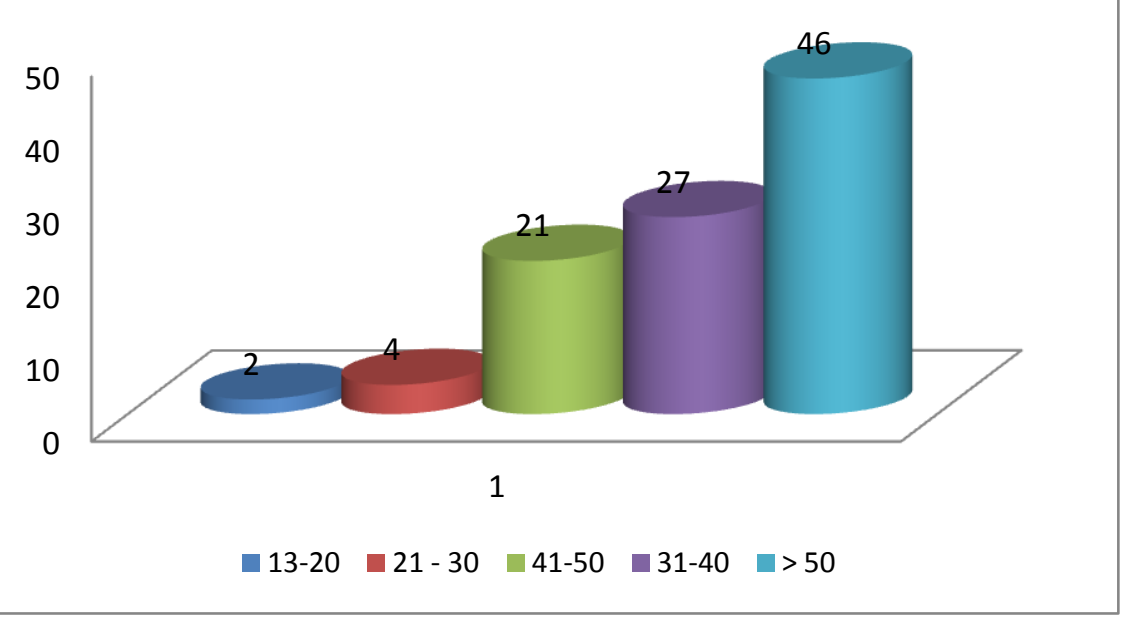

Table 9: Pathology in Arterial Ulcers

\begin{tabular}{|l|c|c|}
\hline PATHOLOGY & No. of Cases & Percentage \\
\hline TAO & 6 & $42.86 \%$ \\
\hline ATHEROSCLEROSIS & 8 & $57.14 \%$ \\
\hline TOTAL & 14 & $100 \%$ \\
\hline
\end{tabular}


Figure 12 : Etiology in Trophic Ulcers

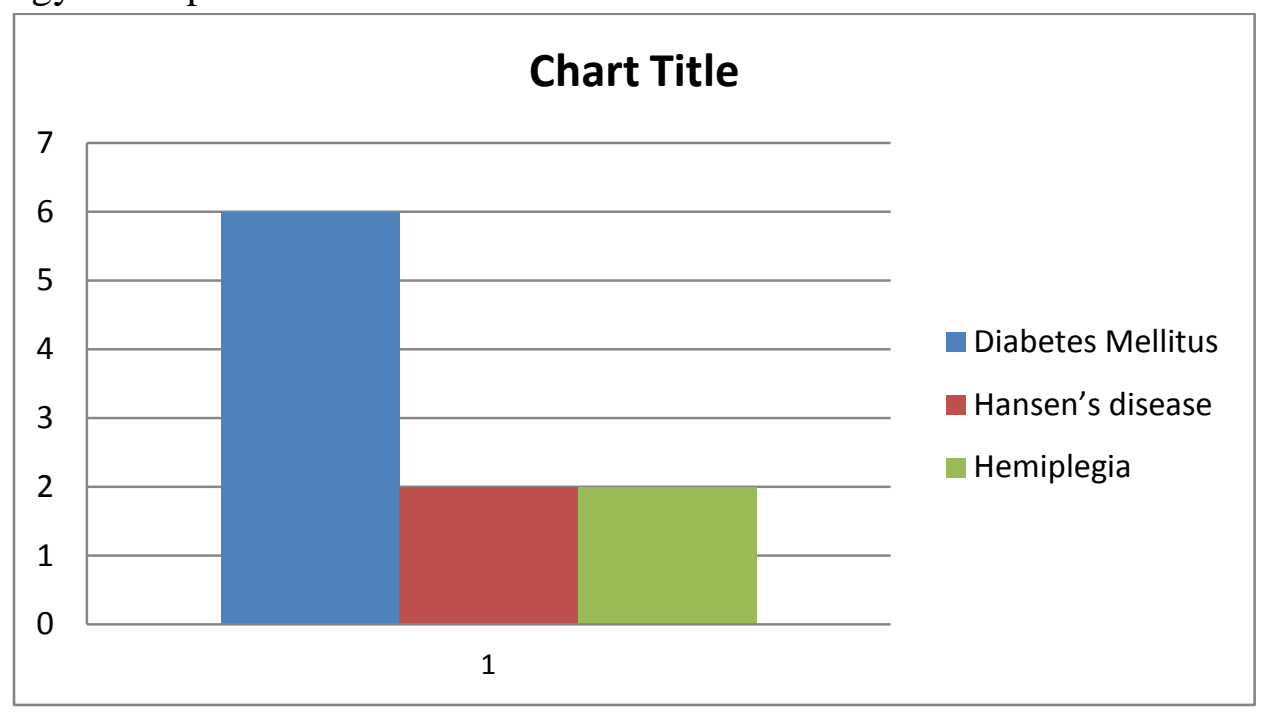

Table 13: Etiology of Malignant Ulcers

\begin{tabular}{|l|c|c|}
\hline ETIOLOGY & No.OF CASES & PERCENTAGE(\%) \\
\hline MARJOLINS ULCER & 3 & 60 \\
\hline SQUAMOUS CELL CARCINOMA & 2 & 40 \\
\hline TOTAL & 5 & 100 \\
\hline
\end{tabular}

Table 15: Types of Bacteria Isolated From Ulcers

\begin{tabular}{|c|c|c|c|c|c|c|}
\hline \multirow[b]{2}{*}{ S. No. } & \multirow[t]{2}{*}{ PATHOGEN } & \multirow{2}{*}{$\begin{array}{l}\text { No. of } \\
\text { Cases }\end{array}$} & \multicolumn{3}{|c|}{ SENSITIVITY } & \multirow[t]{2}{*}{ RESISTANCE } \\
\hline & & & S1 & S2 & S3 & \\
\hline 1 & Staphylococcus & 12 & Amikacin & ceftriaxone & Amoxycillin/clavulanic acid & Ciprofloxacin \\
\hline 2 & Klebsiella & 7 & $\begin{array}{c}\text { Piperacillum+ } \\
\text { Tazobactum }\end{array}$ & Gentamicin & Cefoperazone+sulbactam & Ampicillin \\
\hline 3 & Escherichia coli & 4 & $\begin{array}{c}\text { Cefoperazone+ } \\
\text { sulbactam }\end{array}$ & Amikacin & Amoxycillin/clavulanic acid & Ampicillin \\
\hline 4 & Streptococcus & 8 & Ceftriaxone & Cefalexin & Cefoperazone+sulbactam & Ciprofloxacin \\
\hline 5 & Pseudomonas & 4 & Imipenem & Amikacin & Cefoperazone+sulbactam & $\begin{array}{c}\text { Amoxycillin/clavulanic } \\
\text { acid }\end{array}$ \\
\hline TOTAL & & 35 & & & & \\
\hline
\end{tabular}

Figure 16: Healing Rates of Various types of Lower Limb Ulcers

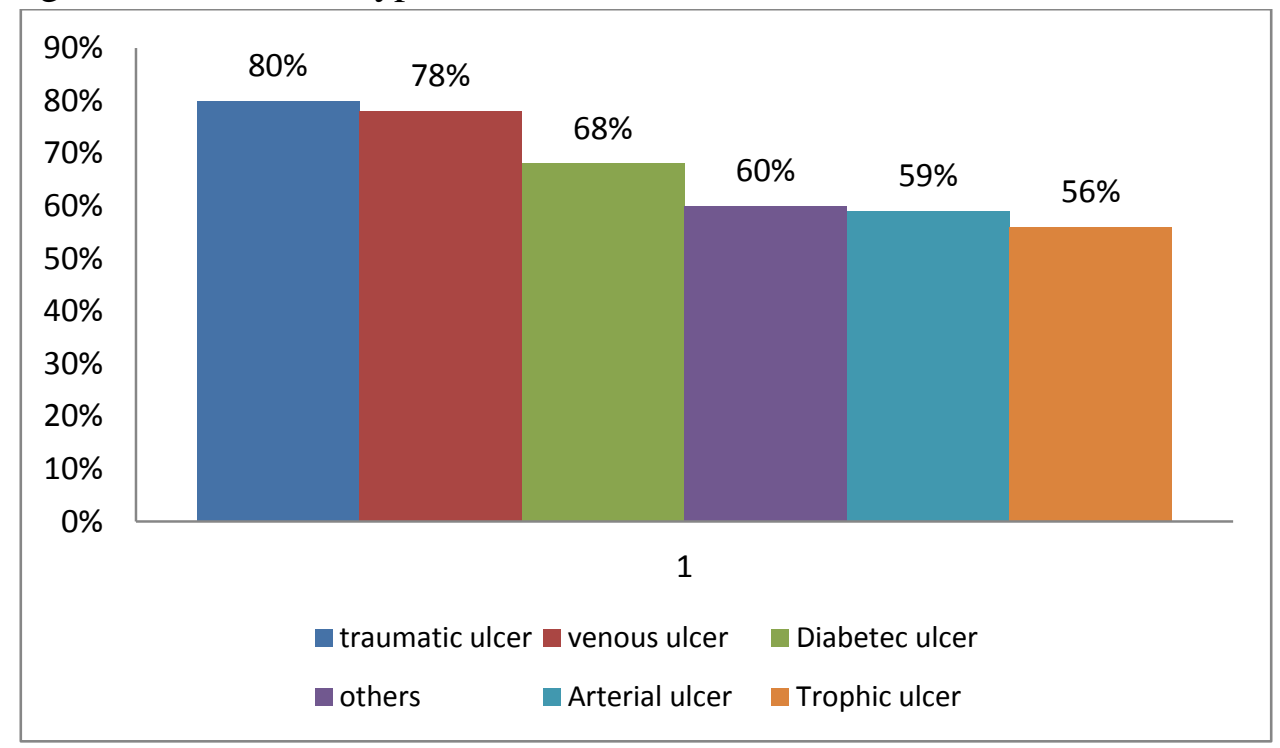


Figure 17: Management of Various Types of Lower Limb Ulcers

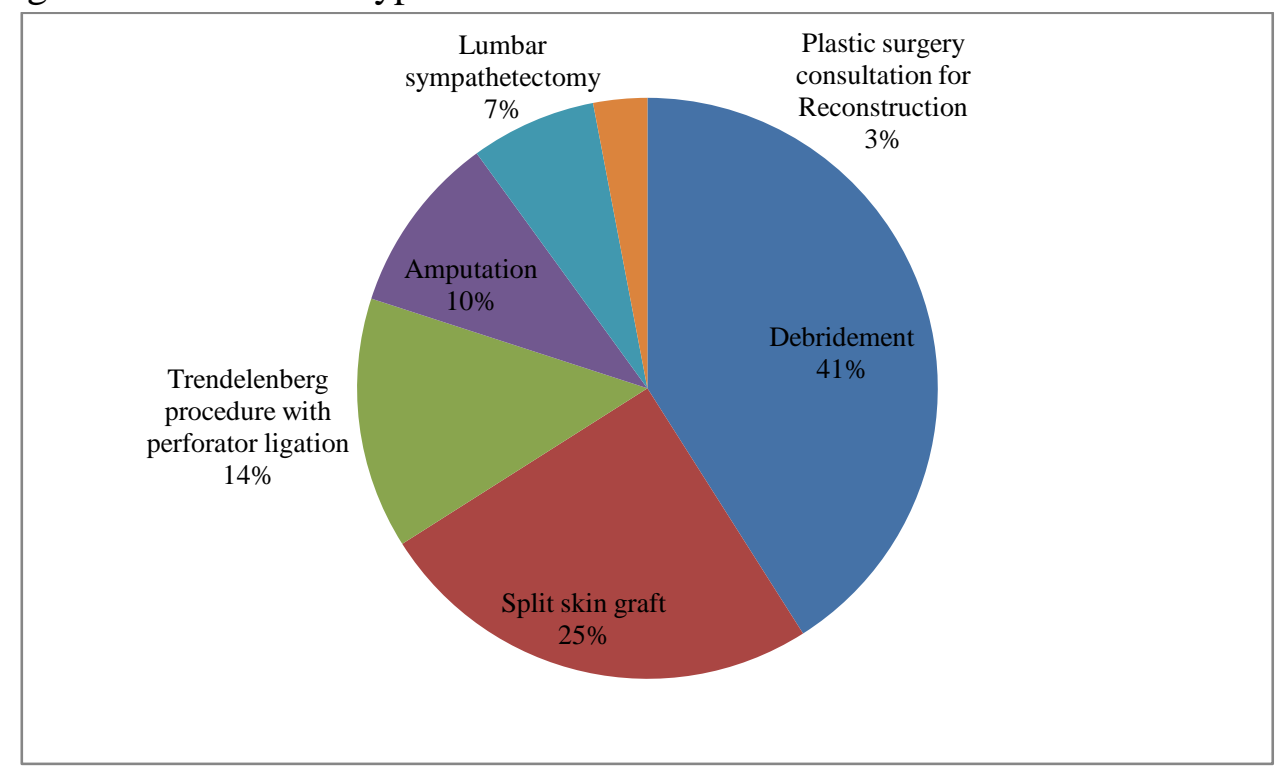

\section{Discussion}

A study from India shows that etiology of chronic wounds included systemic conditions such as diabetes, hypertension atherosclerosis, and leprosy. Other major causes included venous ulcers, pressure ulcers, vasculitis, and trauma. The study report stated that inappropriate treatment of acute traumatic wounds was the most common cause of the chronic wound The majority of these wounds were seen in farmers and other agricultural workers ${ }^{64,65}$.

In this present study, lower limb ulcer with vascular etiology accounted for only $28 \%$ of all chronic ulcers. Out of this venous ulcers accounted for $14 \%$ and arterial ulcers accounted for $14 \%$.

Chronic ulcers associated with diabetes accounted for nearly 29\%. Traumatic ulcers accounted for $18 \%$ of the cases. Trophic ulcers accounted for $10 \%$ of cases. Malignant ulcers accounted for $5 \%$ and other ulcers for $10 \%$.

Cornwall et $\mathrm{al}^{66}$ in their study had $70 \%$ of patients over the age of 70 years. The median age of all patients in this study was 45 years and $44 \%$ of the patients over the age of 45 years and had $70 \%$ of the patients over the age of 70 years. But according to study done by Callam M. J. ${ }^{67}$ the elderly are not the only population at risk:

Hansson Carita promulgated that peripheral vascular diseases occur seven times more commonly in sixty year old patients than twenty year old ${ }^{68}$.

Nevertheless in this study, arterial ulcers were found to be equal in both age groups i.e 41-50 years $(35.7 \%)$; >50years age group $(35.7 \%)$

Venous ulcers were found to be more common in the age group $>50$ years which is in accordance with most of other Western studies.

Traumatic ulcers were found to be more common in age groups $>41$ years with more incidence in males. Trophic ulcers were more common in diabetec patients (60\%)when compared with hemiplegic $(20 \%)$ and hansens disease patients (20\%)

Malignant ulcers were identified in 5 patients out of which 3 patients $(60 \%)$ had marjolins ulcers (post burns) while remaining 2 (40\%) had primary squamous cell carcinoma.

Culture and sensitivity of the exudates was done in cases with purulent discharge. Among the different culture growths obtained, the most common organism was found to be Staphylococcus aureus (40\%) which was more sensitive to Amikacin and followed by Streptococcus pyogenes (26.6\%) which was more sensitive to ceftriaxone .Pseudomonas was isolated from 4 patients which was primarily sensitive to higher antibiotic i.e Imipenem.

Among the twenty nine patients with diabetic ulcers - 5 patients underwent split thickness skin 
grafting, 10 patients underwent ray amputation of toe, 10 patients underwent debridement, 4 patients were managed conservatively. Mean graft uptake in case of diabetic ulcers is found to be $90 \%$.

Previous studies reported 1-year venous ulcer recurrence rates as high as $69 \%$. However, within the ESCHAR trial, recurrence rates for patients treated with compression and venous surgery were $12 \%$ at 1 year and $31 \%$ at 4 years. These were significantly lower than recurrence rates for patients treated with compression alone (28\% at 1 year and $56 \%$ at 4 years) ${ }^{69,70}$.

In this study. $41 \%$ of chronic lower limb ulcers underwent debridement out of which $30 \%$ had diabetec ulcer, $7 \%$ had traumatic ulcer and $4 \%$ had other causes like infected arterial, venous and trophic ulcers. $25 \%$ ofchronic lower limb ulcers underwent split skin graft out of which $14 \%$ had venous ulcer who also underwent respective Greater saphenous vein +perforator ligation, Short saphenous veins +perforator ligation, $6 \%$ had traumatic ulcers and 5\% had diabetic ulcers

$7 \%$ of arterial ulcers with rest pain underwent lumbar sympathetectomy and $3 \%$ of skin malignancies of lower limb that were operable was sent to plastic surgery for wide local excision and reconstruction.

\section{Conclusion}

In the present study, it is demonstrated that lower limb ulcers are debilitating and are seen most often in the elderly. They are therefore a major health issue in an aging population. Majority of the lower limb ulcers are caused by diabetes, followed by traumatic ulcers, venous ulcers and arterial ulcers. A detailed knowledge of the clinical picture, pathogenesis, diagnostic tests, treatment modalities, and differential diagnosis of leg ulcerations is essential in planning the optimal treatment strategy. A delayed diagnosis may harm the patient and increase the risk of serious complications, including permanent disability and amputations.

Patient education regarding their underlying condition and measures to be adopted by them to prevent recurrent ulceration play a prominent role in reducing overall disease burden in the population.

Multi-disciplinary team approach and establishing specialised wound care centres appear to confer a significant, positive impact on reducing recurrent ulcerations and amputations.

\section{References}

1. Bonadeo P In: Guarnera G, Papi M(2000), L'Ulcera cutanea degli arti inferiori. EdMonti, Saronno, Italy.

2. Cutler, Henry (1845). On ulcers their cause and formation. Lancet,2, 262-263.

3. Walker, Richard (1809). Observations on remarkable efficacy of carrots under a new mode of application, in the cure of ulcers and sores. Philosophical magazine, 34, 281.

4. Anning, S. T. (1976). The historical aspects. In: The Pathology and Surgery of the Veins of the Lower Limb. By Dodd, H. \&, Cockett, F. B. 2nd edn. Churchill Livingstone.

5. M Wayne, venous disorders, text book of surgery. The biological methods of modern surgical practice. $15^{\text {th }}$ edition W.B. Saunders comp, 1997.

6. Buerger L : Thromboangitis Obliterans : A study of vascular lesions leading to presenile spontaneous gangrene. American Journal Medical science 136:567-580 ,1908.

7. Marjolin JN: Ulcere: dictionnaire de medicine. Paris, Bechet, 1828.

8. Da Costa JC: carcinomatous changes in an area of chronic ulceration, or Marjolin's ulcer. Ann Surg- 1903, 37, 495-502.

9. Trautman JR, Kirchheimer WF, Prabhakaran K, Hastings RC, Shannon EJ, Jacobson RR, et al. An overview of Carville research. Acta Leprol. 1981 JulSep;(84):1-29.

10. Martorell F. Las ulceros supramaleolares por arteriolitis de las grandes hipertensas. Acta Instituta Plicilinico [Spain] 1945;1:69. 
11. Hines EA Jr, Farber EM. Ulcer of the leg due to arteriosclerosis and ischaemia occurring in the presence of hypertensive disease (hypertensive ischaemic ulcers). A preliminary report. Proceedings of the staff meetings of the Mayo clinic. 1946; 21: 337-46.

12. Koeveker $\quad$ GB(2001): $\quad$ Surgical debridements of wounds. In : Falanga V. Cutaneous wound healing : Martin Dunitz.

13. Reverdin JL: Greffe epidermique. Bull, Soc Imperial Chir Paris, 1869; 10.

14. Tanner JC, Vandeput J, Olley JF et al: The mesh skin graft. Plastic reconstr surg 1964; 34:287-292.

15. Valencia IC, Falabella A, Kirsner RS, Eaglstein WH. Chronic venous insufficiency and venous leg ulceration. J Am Acad Dermatol. 2001;44:401-21.

16. Bergan JJ, Schmid-Schonbein GW, Smith $\mathrm{PD}$, et al. Chronic venous disease. $\mathrm{N}$ Engl J Med. 2006;355:488-98.

17. Mekkes JR, Loots MA, Van Der Wal AC, Bos JD. Causes, investigation and treatment of leg ulceration. Br J Dermatol. 2003; 148:388-401.

18. Thomas PR, Nash GB, Dormandy JA. White cell accumulation in dependent legs of patients with venous hypertension: a possible mechanism for trophic changes in the skin. $\mathrm{Br}$ Med J (Clin Res Ed). 1988;296:1693-5.

19. White C. Clinical practice. Intermittent claudication. N Engl J Med. 2007;356:1241-50.

20. Sumpio BE. Foot ulcers. N Engl J Med. 2000;343:787-93.

21. Mehra NK, et al: Immunogenetics of peripheral arteriopathies. Clin Hemorheol Microcirc 23:225-232, 2000.

22. Lee $\mathrm{T}$, et al: Immunobiologic analysis of arterial tissue in Buerger's disease. Eur J Vasc \& Endovasc Surg 25:451-457, 2003.

23. Williams G: Recent views on Buerger's disease. J Clin Pathol 22:573-578, 1969.
24. Kobayashi M, et al: Immunohistochemical analysis of arterial wall cellular infiltration in Buerger's disease (endarteritis obliterans). J Vasc Surg 29:451-458, 1999.

25. Andersen CA, Roukis TS. The diabetic foot. Surg Clin North Am. 2007;87:1149$77, \mathrm{x}$.

26. Kalish J, Hamdan A. Management of diabetic foot problems. J Vasc Surg. 2010;51:476-86.

27. Falanga V. Wound healing and its impairment in the diabetic foot. Lancet. 2005;366:1736-43.

28. Cavanagh PR, Lipsky BA, Bradbury AW, Botek G. Treatment for diabetic foot ulcers. Lancet. 2005;366:1725-35.

29. Lavery LA, et al: Practical criteria for screening patients at high risk for diabetic foot ulceration. Arch Intern Med 158:157162, 1998.

30. Fernando DJ, et al: Relationship of limited joint mobility to abnormal foot pressures and diabetic foot ulceration. Diabetes Care 14:8-11, 1991.

31. Grant WP, et al: Evaluation of Young's modulus in Achilles tendons with diabetic neuroarthropathy. J Am Podiatr Med Assoc 95:242-246, 2005.

32. Vinita Puri, N Venkateshwaran and Nishant Khare: Trophic ulcersPractical management guidelines. Indian J Plast Surg. 2012 ,May-Aug;45(2):340-351.

33. Young MJ, Cavanagh PR, Thomas G, Johnson MM, Murray H, Boulton AJ. The effect of callus removal on dynamic plantar foot pressures in diabetic patients. Diabet Med. 1992;9:55-7.

34. Raju S, Neglen P. Clinical practice. Chronic venous insufficiency and varicose veins. N Engl J Med. 2009;360:2319-27.

35. Barron GS, Jacob SE, Kirsner RS. Dermatologic complications of chronic venous disease: medical management and beyond. Ann Vasc Surg. 2007;21:652-62 
36. Hafner J, Nobbe S, Partsch $\mathrm{H}$, et al.. Martorell hypertensive ischemic leg ulcer: a model of ischemic subcutaneous arteriolosclerosis. Arch Dermatol 2010; 146: 961-8.

37. Best PJ, Daoud MS, Pittelkow MR, Petitt RM. Hydroxyurea-induced leg ulceration in 14 patients. Ann Intern Med 1998;128:29-32.

38. Milas M, Bush RL, Lin P, Brown K, Mackay G, Lumsden A, et al.Calciphylaxis and nonhealing wounds: the role of the vascular surgeon in a multidisciplinary treatment. J Vasc Surg 2003;37:501-7.

39. M, Adler AI, Neil HA, Matthews DR, Manley SE, Cull CA, et al. Association of glycaemia with macrovascular and microvascular complications of type 2 diabetes (UKPDS 35): Prospective observational study. BMJ. 2000;321:40512.

40. Heehan P, Rosenberg HJ, Schneider JS, Boulton AJ. Evidence-based protocol for diabetic foot ulcers. Plast Reconstr Surg. 2006;117(7 Suppl):193S209S.discussion 210S-211S.

41. Boulton AJ. Pressure and the diabetic foot: clinical science and offloading techniques. Am J Surg. 2004; 187:17S-24S.

42. P, Comerota AJ, Dalsing MC, Eklof BG, Gillespie DL, Gloviczki ML, et al. The care of patients with varicose veins and associated chronic venous diseases: Clinical practice guidelines of the Society for Vascular Surgery and the American Venous Forum. J Vasc Surg. 2011; 53:2S$48 \mathrm{~S}$.

43. Grenon SM, Gagnon J, Hsiang Y. Video in clinical medicine. Ankle-brachial index for assessment of peripheral arterial disease. $\mathrm{N}$ Engl J Med. 2009;361:e40.

44. White C. Clinical practice. Intermittent claudication. N Engl J Med. 2007;356: 1241-50.
45. Malecki R, et al: Thromboangiitis obliterans in the 21 st century - a new face of disease. Atherosclerosis 206:328-334, 2009.

46. Dimmick SJ, et al: Imaging appearances of Buerger's disease complications in the upper and lower limbs. Clin Radiol 67:1207-1211, 2012.

47. Dorweiler B, Neufang A, Kreitner KF, Schmiedt W, Oelert H. Magnetic resonance angiography unmasks reliable target vessels for pedal bypass grafting in patients with diabetes mellitus. J Vasc Surg. 2002;35:766-72.

48. Fonder MA, Lazarus GS, Cowan DA, et al. Treating the chronic wound: a practical approach to the care of nonhealing wounds and wound care dressings. J Am Acad Dermatol. 2008;58:185-206.

49. Lineaweaver W, Howard R, Soucy D, et al. Topical antibiotic therapy. Arch Surg 1985;120:267-270.

50. Steed DL, Donohoe D, Webster MW, Lindsley L. Effect of extensive debridement and treatment on the healing of diabetic foot ulcers. Diabetic Ulcer Study Group. J Am Coll Surg. 1996; 183:61-4.

51. Panuncialman J, Falanga V. The science of wound bed preparation. Surg Clin North Am. 2009;89:611-26.

52. Courtney M. Townsend Jr, Daniel Beauchamp, Mark E, K.L.Mattox, Sabiston Textbook of Surgery; $19^{\text {th }}$ edition Volume 1, Elsevier Saunders, 2013, 172-173.

53. Kulikovsky M, Gil T, Mettanes I, et al : Hyperbaric oxygen therapy for nonhealing wounds, Israel Med Assoc J 11: 480- 485 , 2009.

54. Abidia A, Kuhan G, Laden G : Hyperbaric oxygen therapy for diabetic leg ulcers - A double blind randomized control trial. Eur J Vas and Endovasc surgery 25(6): 513518, 2003. 
55. Hunter JE, Teot L , Horch $\mathrm{R}$,et al: Evidence based medicine: Vacuum assisted closure in wound care management. Int Wound J, 4:256-269, 2007.

56. Javazon EH, Keswani SG, Badillo AT, et al: Enhanced epithelial gap closure and increased angiogenesis in wounds of diabetic mice treated with adult murine bone marrow stromal progenitor cells, Wound repair Regen 15: 350-359, 2007.

57. Fonder MA, Lazarus GS, Cowan DA, et al. Treating the chronic wound: a practical approach to the care of non healing wounds and wound care dressings. J Am Acad Dermatol. 2008;58:185-206.

58. Lau H, et al: Buerger's disease in Hong Kong: a review of 89 cases. Aust N Z J Surg 67:264-269, 1997.

59. Iwase $S$, et al: Skin sympathetic outflow in Buerger's disease. Auton Neurosci 87:286-292, 2001.

60. Singh I, et al: The role of omental transfer in Buerger's disease: New Delhi's experience. Aust N Z J Surg 66:372-376, 1996.

61. P.k. Sarkar and S.Ballantyne, "Management of leg ulcers", Postgraduate medical journal, vol.76, no.901, pp.67482,2000 .

62. M.C.Moloney and P.Grace, "Understanding the underlying causes of chronic leg ulceration," Journal of wound care, vol.13, no.6,pp. 215-218, 2004.

63. V. K. Shukla, M. A. Ansari, and S. K. Gupta, "Wound healing research: a perspective from India," International
Journal of Lower Extremity Wounds, vol. 4, no. 1, pp. 7-8, 2005.

64. X. Fu, Z. Sheng, G. W. Cherry, and Q. Li, "Epidemiological study of chronic dermal ulcers in China," Wound Repair and Regeneration, vol. 6, no. 1, pp. 21-27, 1998.

65. X. Fu, "Skin ulcers in lower extremities: the epidemiology and management in China," International Journal of Lower Extremity Wounds, vol. 4, no. 1, pp. 4-6, 2005

66. Cornwall J. V., Dore C. J. et al. Leg ulcers - Epidemiology and Etiology, Br J Surg, 1986; 73: 693-696.

67. Callam MJ, et al, Chronic Ulcers of the Leg: Clinical History, Br Med J, 1987; 294: 1389-91

68. Hansson Carita, Studies on Leg and Foot Ulcers, Stockholm, Acta Derm Venereol, 1988; 45.

69. Barwell JR, Davies CE, Deacon J, et al. Comparison of surgery and compression with compression alone in chronic venous ulceration (ESCHAR study): randomized controlled trial. Lancet 2004; 363:1854e9.

70. Gohel MS, Barwell JR, Taylor M, et al. Long term results of compression therapy alone versus compression plus surgery in chronic venous ulceration (ESCHAR): randomised controlled trial. $\mathrm{Br}$ Med $\mathrm{J}$, 2007; 335: 83.

71. Brem H, Sheehan P, Rosenberg HJ, Schneider JS, Boulton AJ. Evidence-based protocol for diabetic foot ulcers. Plast Reconstr Surg. 2006;117(7 Suppl):193S209S. discussion 210S-211S. 